\title{
INFLUENCE OF THE PREVEOUS ENZYMATIC TREATMENT OF SEEDS ON THE COMPOSITION OF PRESS PUMPKIN OIL
}

\author{
T. Nosenko, G. Vovk, T. Koroluk \\ National University of Food Technologies \\ O. Golubec \\ State Enterprise "Ukrmetrteststandard"
}

\begin{tabular}{l} 
Key words: \\
Pumpkin oil \\
Enzymes \\
Fatty acids \\
Sterols \\
Tocopherols \\
Non-saponificated \\
substances \\
\hline
\end{tabular}

Article history:

Received 06.09.2018

Received in revised form 28.09.2018

Accepted 22.10.2018

Corresponding author:

T. Nosenko

E-mail:

npnuht@ukr.net

\begin{abstract}
The aim of this work was to investigate the effect of pretreatment of seeds with enzymatic preparations with protease and cellulase activity on the parameters of pumpkin oil composition.
\end{abstract}

Pre-treatment of pumpkin seeds with enzyme preparations was carried out for $2 \mathrm{~h}$ at a temperature of $48-54^{\circ} \mathrm{C}$ with a ratio of protease and cellulase activity as 7:3. Fatty acid composition of the oils was investigated using gas-liquid chromatography. Determination of the isomeric composition of tocopherols was carried out by high-performance liquid chromatography using a reverse phase column. The composition of the sterol fraction was determined after thin-layer separation of the non-saponificated lipids fraction by gas chromatography with a flame-ionization detector.

The obtained results indicate that there are no reliable differences in the composition of fatty acids and phytosterols between the control oil and oil obtained from the seeds after treatment with hydrolytic enzymes. In the oil obtained from the seeds after enzymatic treatment, the total content of tocopherols was $68 \%$ higher than that of the control. The most significant difference was observed in the content of $\delta$ tocopherol, its content in the oil after enzymatic treatment was several times higher compared to the control oil sample. The mass fraction of $\alpha$-tocopherol in the oil sample after enzymatic treatment was close to the optimal concentration for the antioxidant activity of this homologue. The mass concentration of squalene was about $10 \%$ lower in oil extracted from seeds treated with hydrolytic enzymes.

Thus the pretreatment of pumpkin seeds with enzymatic preparations with protease and cellulase activity does not affect the fatty acid and sterol composition of pressed pumpkin oil. Simultaneously, in the oil after enzymatic treatment, the content of tocopherols increased significantly, which positively affects the antioxidant properties of the oil, increasing its oxidation stability, which can extend the shelf life of the oil.

DOI: $10.24263 / 2225-2924-2018-24-5-30$ 


\title{
ВПЛИВ ПОПЕРЕДНЬОЇ ФЕРМЕНТАТИВНОЇ ОБРОБКИ НАСІННЯ НА СКЛАД ПРЕСОВОЇ ГАРБУЗОВОЇ ОЛІЇ
}

\author{
Т.Т. Носенко, Г.О. Вовк, Т.А. Королюк \\ Національний університет харчових технологій \\ О.В. Голубець \\ Державне підприсмство «Укрметртестстандарт»
}

У статті досліджено вплив попередньої обробки насіння ферментними препаратами із протеазною та целюлазною активністю на показники складу гарбузової олії.

Попередню обробку гарбузового насіння ферментними препаратами проводили протягом 2 год за температури $48-54^{\circ} \mathrm{C}$ при співвідношенні протеазної та целюлазної активності як 7:3. Жирнокислотний склад олій досліджували за допомогою газово-рідинної хроматографії. Визначення ізомерного складу токоферолів здійснювали методом високоефективної рідинної хроматографії з використанням колонки з оберненою фазою. Склад стеролової фракиї визначали після тонкошарового розділення неомилюваної фракиї ліпідів газовохроматографічним методом із полум'яно-іонізачійним детектором.

Одержані результати свідчать про відсутність достовірних відмінностей складу жирних кислот і груп фітостеролів між контрольним зразком олії та олією, одержсаною із насіння після його обробки гідролітичними ферментами. В олії, одержаній із насіння після ферментативної обробки, масова частка токоферолів була на 68\% вищою, ніж у контролі. Найбільш суттєва різниия спостерігалась за вмістом $\delta$-токоферолу, його вміст в олії після ферментативної обробки був у кілька разів вищим порівняно із контрольним зразком оліі. Масова частка $\alpha$-токоферолу в експериментальному зразку олії була близькою до оптимальної концентрації для антиоксидантної активності даного гомологу. Масова концентрачія сквалену була приблизно на 10\% нижчою в олії, вилученій із насіння, обробленого гідролітичними ферментами.

Доведено, що попередня обробка гарбузового насіння ферментативними препаратами із протеазною та иелюлазною активністю не впливає на жирнокислотний і стероловий склад пресової гарбузової олії. Одночасно в олії після ферментативної обробки суттєво зріс вміст токоферолів, щео позитивно впливає на антиоксидантні властивості олії, підвищуючи ї̈ стійкість до окиснення, що може подовжити термін придатності олї̈ до споживання.

Ключові слова: гарбузова олія, ферменти, жирні кислоти, стероли, токофероли, неомилювальні речовини.

Постановка проблеми. Використання ензимних технологій у переробці насіння олійних культур було започатковано в технології водно-ферментативного фракціонування насіння. Згодом було запропоновано використання гідролітичних ферментів для підготовки олійного матеріалу до пресового вилучення олії. Зазвичай, для цієї мети використовують целюлази, геміцелюлази, пектинази та протеази. Проте вплив біокаталізаторів на хімічний 
склад вилучених олій остаточно не досліджений. Зокрема, в науковій літературі не наведені дані щодо впливу попередньої ензимної обробки на хімічний склад олії із насіння гарбузів.

Аналіз останніх досліджень і публікацій. Для підвищення ефективності водного екстрагування олії та білків з олійного насіння було запропоновано використовувати гідролітичні ферменти 3 метою руйнування клітинних оболонок, а також білкових каркасів, що оточують олеосоми. Так, в [1] виявлено, що використання протеаз у процесі водного екстрагування соєвого борошна давало можливість збільшити вихід олії на $25 \%$, проте ступінь інтенсифікації залежав від інших параметрів екстрагування. Високого виходу екстрагованої олії (88-99\%) за наявності протеаз із екструдованих розмелених соєвих бобів або пластівців було досягнуто також у дослідженнях [2; 3].

Механізм дії гідролітичних ферментів на олійний матеріал полягає в гідролізі нерозчинних вуглеводів і білків, їх розчиненні, внаслідок чого звільняється додаткова кількість олії, заблокованої в окремих компартментах [4; 5]. Недоліком водно-ферментативного екстрагування олійної сировини $\epsilon$ необхідність руйнування емульсії, яка утворюється, та повне вилучення олії.

Водночас технології попередньої ферментативної обробки олійного матеріалу були запропоновані як спосіб підготовки матеріалу до пресового вилучення олії. 3 цією метою, зазвичай, використовують целюлазу, геміцелюлазу, пектиназу та протеази. Показано, що після попередньої обробки насіння карбогідразами та протеазами збільшувався вихід пресової ріпакової [6], конопляної [7], соєвої [8], лляної [9] олії. У [9] виявлено, що більшість фізикохімічних показників, таких як показник заломлення, густина, йодне число, вміст вільних жирних кислот, число омилення, колір і профіль жирних кислот істотно не відрізнялись між олією із контрольного та насіння, попередньо обробленого ферментами. Одночасно вміст пероксидів, анізидинове число, вміст кон'югованих дієнів, триєнів і профіль окиснення (метод Рансімат) були вищими у лляної олії, вилученої після ензимної обробки, порівняно із контролем.

Дослідження впливу ферментативної обробки олійної сировини на якість пресової конопляної олії не виявили значної відмінності значень йодного показника, показника заломлення, густини, неомилених речовин і складу жирних кислот контрольного зразка пресової олії та олії, вилученої із насіння після ферментативної обробки [7]. Значення числа омилення, вмісту вільних жирних кислот, йодного та пероксидного числа досліжених зразків олії дещо відрізнялись. Показано, що олія, вилучена з конопляного насіння, попередньо обробленого ферментними препаратами із целюлазною та протеазною активністю, мала відносно більш високий вміст токоферолів $(4,8-14,1 \%)$, а також вищу окиснювальну стабільність (Рансімат-тест) [7].

Результати дослідження впливу попередньої ферментативної обробки на якісні показники та компонентний склад рослинної олії, представлені в опублікованих джерелах, $є$ дещо суперечливі.

Мета дослідження: оцінити вплив ферментних препаратів із протеазною та целюлазною активністю на показники складу олії з насіння гарбузів. 
Матеріали і методи. Попередню обробку подрібненого гарбузового насіння ферментними препаратами проводили протягом 2 год за температури $48-54^{\circ} \mathrm{C}$ при співвідношенні протеазної та целюлазної активності як 7:3. Висушування насіння проводили за температури $(80 \pm 5)^{\circ} \mathrm{C}$ до значення вологості $7,0 \%$. Із підготовленого насіння олію вилучали на лабораторному шнековому пресі за температури $(60 \pm 5)^{\circ} \mathrm{C}$.

Жирнокислотний склад олій досліджували за допомогою газово-рідинної хроматографії $[10 ; 11]$ на газовому хроматографі Agilent Technologies 7890 iз застосуванням капілярної колонки Zebron FAME (Phenomenex) довжиною 100 м, з внутрішнім діаметром 0,25 мм та товщиною нерухомої фази 0,2 мкм за таких умов: швидкість потоку газу-носія - 1,2 мл/хв, коефіцієнт поділу потоку $-1: 100$, температура випаровувача $-280^{\circ} \mathrm{C}$, температура детектора (ПІД) $-290^{\circ} \mathrm{C}$. Об’єм інжекції -1 мкл. Температурний режим колонки поступове нагрівання від $60^{\circ} \mathrm{C}$ до $260^{\circ} \mathrm{C}$ :

- витримування при $60^{\circ} \mathrm{C}-4$ хв;

- нагрівання від 60 до $150^{\circ} \mathrm{C}$ із швидкістю $4^{\circ} \mathrm{C} / \mathrm{xв}$, витримування при $150^{\circ} \mathrm{C}$ $10 \mathrm{xB}$;

- нагрівання від 150 до $180^{\circ} \mathrm{C}$ із швидкістю $3^{\circ} \mathrm{C} / \mathrm{xв}$, витримування при $180^{\circ} \mathrm{C}-5$ хв;

- нагрівання від 180 до $190^{\circ} \mathrm{C}$ із швидкістю $3^{\circ} \mathrm{C} /$ хв, витримування при $190^{\circ} \mathrm{C}-2 \mathrm{xв}$;

- нагрівання від 190 до $230^{\circ} \mathrm{C}$ із швидкістю $3^{\circ} \mathrm{C} /$ хв, витримування при $230^{\circ} \mathrm{C}-2 \mathrm{xв}$;

- нагрівання від 230 до $260^{\circ} \mathrm{C}$ із швидкістю $4^{\circ} \mathrm{C} / \mathrm{xв}$, витримування при $260^{\circ} \mathrm{C}-2$ хв.

Приготування метилових ефірів жирних кислот. Для приготування метилових ефірів жирних кислот 100 мг олії розчиняли в $2 \mathrm{~cm}^{3}$ розчину бутилгідрокситолуолу (ВНТ) у гептані масовою часткою $0,05 \%$. Одержаний розчин змішували протягом 2 хв із 100 мкл розчину натрію в метанолі масовою концентрацією 46 мкг $/ \mathrm{cm}^{3}$ і витримували 15 хв. Додавали до суміші $1-2$ г гідросульфату натрію, промивали пробу водою та фільтрували через безводний $\mathrm{Na}_{2} \mathrm{SO}_{4}$ для зневоднення і додавали $2 \mathrm{~cm}^{3} 0,05 \%$ розчину ВНТ в гептані, струшували і фільтрували через 0,45 мкм мембранний целюлозний фільтр. Фільтр промивали за допомогою $1 \mathrm{~cm}^{3} 0,05 \%$ розчину ВНТ в гептані, фільтрати об'єднували та використовували для аналізу метилових ефірів жирних кислот.

Для ідентифікації хроматографічних піків та обрахунку хроматограм використовували суміш метилових ефірів жирних кислот - 37 Component FAME Mix, Supelco (кат. № 47885-U). Реєстрацію та обробку хроматограм здійснювали за допомогою персонального комп'ютера, оснащеного програмним забезпеченням HP ChemStation.

Визначення ізомерного складу токоферолів методом ВЕРХ з використанням колонки з оберненою фазою [12].

До наважки олії у круглодонній колбі масою 2 г додавали $50 \mathrm{~cm}^{3}$ метилового спирту, 0,25 г аскорбінової кислоти, $5 \mathrm{~cm}^{3} 350$ г/100 $\mathrm{cm}^{3}$ розчину гідроксиду калію і проводили омилення на водяній бані за температури $80-100^{\circ} \mathrm{C}$ протягом 15-40 хвилин. 
Неомилені речовини екстрагували тричі диетиловим ефіром. Об'єднаний екстракт промивали дистильованою водою і висушували сульфатом натрію протягом 30 хвилин. Після цього ефір відганяли на роторному випарювачі при температурі $40-50^{\circ} \mathrm{C}$, а залишок розчиняли у метиловому спирті й кількісно переносили у мірну колбу місткістю $10 \mathrm{~cm}^{3}$. Доводили об'єм розчину метанолом до мітки, закривали і перемішували. Отриманий екстракт використовували для хроматографічного визначення вітамінів.

Для дослідження використовували рідинний хроматограф Hewlett-Packard HР 1100 з флуоресцентним (довжина хвилі збудження 295 нм, поглинання 330 нм) та діодно-матричним детекторами, обернено-фазовою колонкою Нуpersil MOS діаметром 2,1мм, довжиною 200 мм. Умови хроматографування: мобільна фаза ацетонітрил:вода (70:80), швидкість потоку $0,4 \mathrm{~cm}^{3} / \mathrm{xв}$, температура термостату $40^{\circ} \mathrm{C}$.

Реєстрували не менше п'яти хроматограм кожного розчину. 3 отриманих значень площ хроматографічних піків знаходили середнє арифметичне (розходження між отриманими величинами не повинно перевищувати $10 \%$ ). За одержаними даними будували градуювальні залежності площі піка від концентрації компонента.

На хроматограмах ідентифікували компоненти за часом утримання піків на хроматограмах контрольних розчинів. Кількісне визначення проводили 3 урахуванням площі піків.

Визначення складу стеролової фракиії. До досліджуваного зразка олії масою 100 мг додавали $10 \mathrm{~cm}^{3}$ стандартного розчину бетуліну та $100 \mathrm{~cm}^{3}$ спиртового розчину $\mathrm{KOH}$ і кип'ятили на водяній бані 1 годину. Після охолодження пробу переносили у ділильну лійку, додаючи $200 \mathrm{~cm}^{3}$ дистильованої води i $100 \mathrm{~cm}^{3}$ діетилового ефіру, енергійно струшували та відокремлювали верхній ефірний шар. Промивання повторювали тричі. Об'єднані ефірні екстракти переносили в іншу ділильну лійку, додаючи $100 \mathrm{~cm}^{3}$ дистильованої води, обережно струшуючи. Після розшарування водний шар зливали і промивання повторювали тричі. Верхній ефірний розчин фільтрували крізь шар сульфату натрію. Випаровували розчинник на ротаційному плівковому випарнику до одержання $1 \mathrm{~cm}^{3}$ розчину. За допомогою мікрошприца наносили розчин на підготовлену кремнієву пластинку і ставили іiі у бак проявника. Після розгонки пластинку виймали, даючи розчиннику випаритися. Мікрошпателем збирали кремній, що містив стеролову фракцію. Кремній клали у конічну колбу, додавали $5 \mathrm{~cm}^{3}$ діетилового ефіру і кип'ятили на водяній бані 15 хв. Розчин охолоджували і фільтрували через паперовий фільтр. Кремній 3 фільтрувального паперу повторно екстрагували і фільтрували ще двічі. Залишок розчиняли в мінімальній кількості розчинника для проявлення й аналізували шляхом хроматографії у газовій фазі.

Детекцію проводили згідно 3 [13] на газовому хроматографі СР-3800 (Varian), обладнаному полум'яно-іонізаційним детектором, системою електронного управління потоками газів, універсальним інжектором для введення зразків у режимах з розділенням та без розділення потоків та автосемплером (CР-8410 Varian). Використано капілярну колонку MET-Biodiesel iз вбудованою передколонкою, довжина колонки 14 м, внутрішній діаметр 0,53 , тов- 
щина нерухомої фази 0,16 мкм за таких умов: швидкість потоку газу-носія $5,0 \mathrm{~cm}^{3} / \mathrm{xв}$, коефіцієнт поділу потоку — 1:10, температура випаровувача $360^{\circ} \mathrm{C}$, температура детектора $-390^{\circ} \mathrm{C}$, температурний режим колонки поступове нагрівання від $160^{\circ} \mathrm{C}$ до $340^{\circ} \mathrm{C}$. Об'єм інжекції -1 мкл.

Результати і обговорення. Як свідчать одержані нами дані, попередня обробка подрібненого гарбузового насіння ферментними препаратами протягом 2 год за температури $48-54^{\circ} \mathrm{C}$ при співвідношенні протеазної та целюлазної активності як 7:3 призводила до збільшення виходу пресової гарбузової олії приблизно на 8\%. Така обробка не супроводжувалась інтенсифікацією перебігу окиснювальних процесів — одержана олія за значенням пероксидного числа не відрізнялась від контролю.

Аналіз жирнокислотного складу досліджуваних зразків олії свідчить, що основними жирними кислотами є поліненасичена лінолева та мононенасичена олеїнова кислот. Їх сумарний вміст становить приблизно $81 \%$ від загального вмісту жирних кислот (табл. 1). Понад 17\% жирних кислот складають насичені жирні кислоти, основні з яких - пальмітинова та стеаринова. Достовірних відмінностей складу жирних кислот між досліджуваними зразками олій не виявлено.

Таблиця 1. Склад жирних кислот у досліджуваних зразках гарбузової олії

\begin{tabular}{|c|c|c|c|}
\hline \multirow[b]{2}{*}{ № } & \multirow[b]{2}{*}{ Жирна кислота } & \multicolumn{2}{|c|}{$\begin{array}{c}\text { Масова частка жирної кислоти, \% від } \\
\text { загального вмісту }\end{array}$} \\
\hline & & $\begin{array}{c}\text { Олія із насіння, } \\
\text { обробленого в } \\
\text { контрольних умовах }\end{array}$ & $\begin{array}{c}\text { Олія після попередньої } \\
\text { ферментативної } \\
\text { обробки насіння }\end{array}$ \\
\hline 1 & C 16:0 & $11,57 \pm 0,15$ & $11,40 \pm 0,15$ \\
\hline 2 & cis-9-C 16:1 & $0,16 \pm 0,05$ & $0,16 \pm 0,05$ \\
\hline 3 & C 18:0 & $5,51 \pm 0,10$ & $5,37 \pm 0,10$ \\
\hline 4 & cis-9-C 18:1 & $34,92 \pm 0,20$ & $34,91 \pm 0,20$ \\
\hline 5 & cis-11-C 18:1 & $0,80 \pm 0,15$ & $0,79 \pm 0,15$ \\
\hline 6 & cis, cis-9,12-C 18:2 & $45,95 \pm 0,20$ & $46,29 \pm 0,20$ \\
\hline 7 & C $20: 0$ & $0,40 \pm 0,05$ & $0,39 \pm 0,05$ \\
\hline 8 & cis,cis,cis-9,12,15-C 18:3 & $0,20 \pm 0,20$ & $0,20 \pm 0,20$ \\
\hline 9 & cis-11-C 20:1 & $0,11 \pm 0,10$ & $0,10 \pm 0,10$ \\
\hline 10 & C 22:0 & $0,13 \pm 0,05$ & $0,13 \pm 0,05$ \\
\hline 11 & C 24:0 & Не виявлено & $0,07 \pm 0,05$ \\
\hline \multicolumn{4}{|c|}{ Групи жирних кислот: } \\
\hline & насичені & 17,79 & 17,54 \\
\hline & мононенасичені & 35,99 & 35,97 \\
\hline & поліненасичені & 46,22 & 46,49 \\
\hline
\end{tabular}

Важливим показником хімічного складу рослинних олій є вміст стеролової фракції. Тривалий час вважали, що ці речовини не надають особливих властивостей оліям і жирам [14]. Проте пізніше було встановлено, що фітостероли інгібують реакції полімеризації в оліях під час термічної обробки. Згодом було виявлено, що вони здатні зменшувати вміст холестеролу та ліпідів низької густини в сироватці крові. Співвідношення між окремими представниками стеролів у досліджених зразках гарбузової олії практично не відріз- 
нялось (табл. 2). Основними представниками фітостеролів у гарбузовій олії $\epsilon$ $7,22,25$-стигмастатриєнол та $\alpha$-спінастерол, масова частка яких становить понад 50\% від загального вмісту стеролів.

Таблиця 2. Склад стеролової фракції у досліджуваних зразках гарбузової олії

\begin{tabular}{|c|c|c|}
\hline \multirow[b]{2}{*}{ Стерол } & \multicolumn{2}{|c|}{ Масова частка, \% від загального вмісту } \\
\hline & $\begin{array}{c}\text { Олія із насіння, } \\
\text { обробленого в } \\
\text { контрольних умовах }\end{array}$ & $\begin{array}{c}\text { Олія після попередньої } \\
\text { ферментативної обробки } \\
\text { насіння }\end{array}$ \\
\hline Кампестерол & 3,65 & 3,95 \\
\hline Стигмастерол & 2,10 & 1,93 \\
\hline 24-метилхолест-7-єнол & 1,63 & 2,01 \\
\hline $\begin{array}{c}\text { 7,22,25-Стигмастатриєнол+ }+\alpha- \\
\text { Спінастерол }\end{array}$ & 51,86 & 52,99 \\
\hline$\Delta$-5-авенастерин & 2,07 & 2,48 \\
\hline 7,25-Стигмастадиєнол & 24,17 & 25,07 \\
\hline$\Delta$-7-стигмастерин & 5,84 & 6,42 \\
\hline$\Delta-7$-авенастерин & 8,69 & 5,15 \\
\hline $\begin{array}{c}\text { Сумарна масова частка стеролів, } \\
\text { мг/кг олії }\end{array}$ & $3242,1 \pm 78$ & $3133,7 \pm 67$ \\
\hline
\end{tabular}

Відомо, що найбільш потужними антиоксидантами у рослинних оліях $\epsilon$ токофероли. Найбільш ефективним антиоксидантом серед токоферолів $\epsilon \alpha$ токоферол, він має найнижчий оптимум концентрації антиоксидантної активності: $10-25$ мг \% [15].

Аналіз складу гомологів токоферолів та їх загального вмісту у дослідних зразках олії свідчить, що в олії, одержаній із насіння після його обробки гідролітичними ферментами, масова частка токоферолів була на $68 \%$ вищою, ніж у контролі (табл. 3). Найбільш суттєва різниця спостерігалась за вмістом $\delta$-токоферолу, його вміст в олії після ферментативної обробки був майже у чотири рази вищим порівняно 3 контрольним зразком олії. Масова частка $\alpha$-токоферолу в експериментальному зразку олії була близькою до оптимальної концентрації для антиоксидантної активності даного гомологу. За вмістом $\beta$-каротину зразки олії відрізнялись несуттєво. Масова концентрація сквалену, який також входить до неомилювальної фракції ліпідів, була приблизно на $10 \%$ нижчою в олії, вилученій із насіння, обробленого гідролітичними ферментами (табл. 3).

Таблиця 3. Вміст неомилювальних ліпідів у зразках гарбузової олії

\begin{tabular}{|c|c|c|c|c|c|c|}
\hline \multirow{2}{*}{ Олія } & \multicolumn{4}{|c|}{ Токофероли, мкг/г } & $\begin{array}{c}\text { Сквален, } \\
\text { мкг/ } /\end{array}$ & $\begin{array}{c}\beta \text {-каротин, } \\
\text { мкг/г }\end{array}$ \\
\cline { 2 - 7 } & $\alpha$ & $\beta+\gamma$ & $\delta$ & сума & & \\
\hline $\begin{array}{c}\text { Олія із насіння, } \\
\text { обробленого в } \\
\text { контрольних } \\
\text { умовах }\end{array}$ & $88,67 \pm 0,52$ & $8,28 \pm 0,26$ & $27,04 \pm 0,38$ & 123,99 & $1045,3 \pm 1,07$ & $29,56 \pm 0,39$ \\
\hline $\begin{array}{c}\text { Олія після } \\
\text { попередньої } \\
\text { ферментативної } \\
\text { обробки насіння }\end{array}$ & $96,47 \pm 0,61$ & $12,06 \pm 0,51$ & $100,00 \pm 0,54$ & 208,53 & $895,2 \pm 1,21$ & $28,33 \pm 0,47$ \\
\hline
\end{tabular}




\section{Висновки}

Одержані дані свідчать, що попередня обробка гарбузового насіння гідролітичними ферментами не має суттєвого впливу на жирнокислотний склад вилученої гарбузової олії. В олії, вилученій із гарбузового насіння після ферментативної обробки, виявлено значне збільшення вмісту токоферолів, що може забезпечувати високу антиоксидантну здатність такої олії. У той же час така олія не відрізнялась від контрольного зразка за співвідношенням окремих представників стеролів, масовою часткою $\beta$-каротину, а вміст сквалену в ній був дещо нижчим. Отже, використання попередньої обробки гарбузового насіння гідролітичними ферментами не має негативного впливу на показники складу пресової гарбузової олії та може підвищувати ії стійкість до окиснення.

\section{Література}

1. Latif S., Anwar F. Aqueous enzymatic sesame oil and protein extraction. Food Chem. 2011. V. 125. No. 2. P. 679-684.

2. Lamsal B.P., Murphy P.A., Johnson L.A. Flaking and extrusion as mechanical treatments for enzyme-assisted aqueous extraction of oil from soybeans. J. Am. Oil Chem. Soc. 2006. V. 83. No. 11. P. 973-979.

3. Moura J. M., Campbell K. A., Mahfuz A. et al. Enzyme-assisted aqueous extraction of oil and protein from soybeans and cream de-emulsification. J. Am Oil. Chem. Soc. 2008. V. 85. No. 10. P. $985-995$.

4. Jung S., Mahfuz A., Maurer D. Structure, protein interactions and in vitro protease accessibility of extruded and pressurized full-fat soybean flakes. J. Am. Oil Chem. Soc. 2009. V. 86. No. 3. P. 475- 483.

5. Towa L.T., Kapchie V.N., Hauck C. et al. Enzyme assisted aqueous extraction of oil from isolated oleosomes of soybean flour. J. Am. Oil Chem. Soc. 2010. V. 87. No. 3. P. 347-354.

6. Cherstva A., Lastovetska A, Nosenko T. Using of enzymes to extract of rapeseed oil by pressing. Ukrainian Journal of Food Science. 2016. V. 4. No. 1. P. 85-92.

7. Latif S., Anwar F. Physicochemical studies of hemp (Cannabis sativa) seed oil using enzyme-assisted cold-pressing. Eur. J. Lipid Sci. Technol. 2009. No. 111. P. 1042-1048.

8. Bargale P.C., Sosulski K., Sosulski F.W. Enzymatic hydrolysis of soybean for solvent and mechanical oil extraction. J. Food Process. Engineer. 2000. V. 23. P. 321-327.

9. Anwar F., Zreen Z., Sultana B., Jamil A. Enzyme-aided cold pressing of flaxseed (Linum usitatissimum L.): Enhancement in yield, quality and phenolics of the oil. Grasas y aceites. 2013. V. 64. P. $463-471$.

10. Жири та олії тваринні й рослинні. Аналізування методом газової хроматографії метилових ефірів жирних кислот (ISO 5508:1990, IDT): ДСТУ ISO 5508-2001. Введ. в дію 01.01.2003. Київ: Держспоживстандарт України, 2002. 15 с.

11. Жири та олії тваринні і рослинні. Приготування метилових ефірів жирних кислот (ISO 5509:2000, IDT): ДСТУ ISO 5509-2002. Введ. в дію 01.10.2003. Київ: Держспоживстандарт України, 2003. 27 с.

12. Жири та олії тваринні і рослинні. Вимірювання a-, b-, g-, d-токоферолів (EN12822:2000, IDT): ДСТУ EN 12822:2005. Введ. в дію 01.07.2006. Київ: Держспоживстандарт України, 2006. $20 \mathrm{c}$.

13. ISO 12228-1:2014 Determination of individual and total sterols contents - Gas chromatographic method. Part 1: Animal and vegetable fats and oils. $5 \mathrm{p}$.

14. O'Brien, Richard D. Fats and oils : formulating and processing for applications / by Richard D. O'Brien. 2004. CRC Press, Boca Raton. 574 p.

15. Huang S.W., Frankel E.N., German J.B. Antioxidant Activity of $\alpha$ and $\gamma$-Tocopherols in Bulk Oils and in Oil-in-Water Emulsions. J. Agric. Food Chem. 1994. V. 42. No. 10. P. 2108 2114. 